\title{
真菌血症症例 84 例の検討
}

\author{
順天堂大学医学部内科 (感染症), *同 付属病院中央臨床検査室 \\ 中澤 信八 森健 日比谷一郎 小栗 豊子* \\ (平成 3 年 11 月 19 日受付) \\ (平成 3 年 12 月 20 日受理)
}

Key words: fungal septicemia, fungal endophthalmitis, candidemia, fungemia due to $T$. beigelii

\begin{abstract}
要旨
1986年から1990年までの 5 年間に, 経静脈高カロリー栄養（IVH）のため挿入されたカテーテルから の採血を含め, 動・静脈血液培養で, 真菌が検出された症例84例について検討した。検出真菌は Candida albicans を単独に検出したものが $39.3 \%, C$. parapsilosis 単独が $20.2 \%, C$. tropicalis 単独が $11.9 \%, C$. glabrata が10.7\%, C. guilliermondii が4.8\%, Trichosporon beigelii が4.8\%の順であった. 84例中男 性が59例，女性25例で，男性に多く認められたが，死亡例は46例で，死亡率（54.8\%）には検出真菌抒 よび男女差が認められなかった。全ての症例に基礎疾患があり，24例に剖検が行われ，8例に真菌性病 変が認められたが, そのうち肺クリプトコックス症の 1 例と肺ペニシリウム症 1 例は, 血中から培養さ れた真菌とは関連が認められなかった。 しかし T. beigelii 検出例 4 例では 2 例が死亡し, 共に真菌病変 が認められた。今後注目すべきであろう。血液培養で真菌を検出後, 無処置の場合は $72.7 \%$ 死亡して おり, しかも剖検で深在性真菌症を認め, 血液培養で検出された真菌と関連ありと考兄られたものが 6 例存在した。一方カテーテル抜去のみを行った場合, 死亡率は $41.7 \%$ に減少していた。 また真菌性眼内 炎を 6 例に認めた。従って血液培養で真菌を検出した場合, 先ずカテーテルを抜去し, 繰り返し眼内炎 の有無を検索すべきであろう，抜去後も解熱しない場合は，早急に治療を開始すべきである。
\end{abstract}

\section{序文}

化学療法の進歩に加光て経静脈高カロリ一栄養 (Intravenous hyperalimentation, IVH) の沉用 などにより，全身状態が悪化した患者の延命が可 能になった。しかし，それと共に深在性真菌症の 増加が指摘されているが, 真菌血症もまた増加傾 向にある(1) 4). ところが検出真菌の大多数を占め る Candida spp. は生体の normal flora の一部を 形成して扣り，各種の検査材料から検出されたと しても，その病原的意義を決定することは, 難し いことが多い，治療を行って改善したとして，検 出真菌が果たして病原的意義を有していたかどう か，疑問が残ることがある。しかし血清学的補助

\footnotetext{
別刷請求先：（干113）東京都文京区本郷 2-1-1 順天堂大学医学部内科学講座 (感染症) 中澤 信八
}

診断法が確立されていないこともあって, 治療開 始が遅れ，また確実に奏効する薬剂が少ないこと もあって，その予後を悪くしていることもまた事 実である。

今回, 我々の病院の中央臨床検査室に和いて, IVH のための留置カテーテルから採取した血液 を含め, 動・静脈血液培養検査で, 真菌が検出さ れた症例を臨床的に検討したので，その結果を報 告する。

\section{材料と方法}

1986年から1990年末での 5 年間に, IVH カテー テルからの採血を含めた血液培養で，真菌を検出 し, 病歷が明瞭な84症例について検討した。 84例 のなかには, 腹部大動脈瘤が破裂し, 手術時に大 動脈と腸管の間に瘻孔形成が見られ，術後に真菌 血症を起こし治療で改善した後, 翌年に人工血管 
Table 1 Fungi isolated from blood cultures

\begin{tabular}{|c|c|c|c|c|c|c|c|}
\hline & 1986 & 1987 & 1988 & 1989 & 1990 & Total & $\begin{array}{l}\text { (Isolation } \\
\text { rate) }\end{array}$ \\
\hline Candida albicans & $4(2)$ & $9(5)$ & $10(5)$ & $7(4)$ & $3(2)$ & $33(18)$ & $(39.3 \%)$ \\
\hline Candida parapsilosis & $3(2)$ & $5(3)$ & $4(2)$ & 3 & 2 & $17(7)$ & $(20.2 \%)$ \\
\hline Candida tropicalis & $2(2)$ & $1(1)$ & $3(1)$ & $3(2)$ & 1 & $10(6)$ & $(11.9 \%)$ \\
\hline Candida glabrata & $3(2)$ & $4(4)$ & 1 & $1(1)$ & & $9(7)$ & $(10.7 \%)$ \\
\hline Candida guilliermondii & & & $4(2)$ & & & $4(2)$ & $(4.8 \%)$ \\
\hline Candida krusei & 1 & & & & & 1 & $(1.2 \%)$ \\
\hline $\begin{array}{l}\text { Candida spp. } \\
\text { (not identified) }\end{array}$ & $1(1)$ & & & & & 1 (1) & $(1.2 \%)$ \\
\hline Trichosporon beigelii & $1(1)$ & $1(1)$ & $2(2)$ & & & $4(4)$ & $(4.8 \%)$ \\
\hline Sporothrix & 1 & & & & & 1 & $(1.2 \%)$ \\
\hline $\begin{array}{l}\text { Candida albicans and } \\
\text { Candida tropicalis }\end{array}$ & $1(1)$ & & & & & $1(1)$ & $(1.2 \%)$ \\
\hline $\begin{array}{l}\text { Candida albicans and } \\
\text { Candida glabrata }\end{array}$ & & & & 1 & & 1 & $(1.2 \%)$ \\
\hline $\begin{array}{c}\text { Candida tropicalis and } \\
\text { Candida glabrata }\end{array}$ & 1 & & & & & 1 & $(1.2 \%)$ \\
\hline $\begin{array}{l}\text { Candida parapsilosis } \\
\text { and Candida glabrata }\end{array}$ & & & & & 1 & 1 & $(1.2 \%)$ \\
\hline Total & $18(11)$ & $20(14)$ & $24(12)$ & $15(7)$ & $7(2)$ & $84(46)$ & \\
\hline Mortality rate & $61.1 \%$ & $70.0 \%$ & $50.0 \%$ & $46.7 \%$ & $28.6 \%$ & & \\
\hline
\end{tabular}

( ) : number of deaths.

から再度感染した症例と，約 10 カ月入院期間中 に，4 カ月の間隔を拈いて血液培養で真菌陽性の エピソードを 2 回認めた症例はそれぞれ 2 例とし て算定した。

病理所見は提出された病理解剖報告をもとにし たが，解剖例全例に培養検査が行われたわけでは なく，原因真菌の菌種まで決定されていない症例 があった。クリプトコックス症は形態学的に明ら かにそれと特定されていたが, Trichosporon beigelii は Candida spp. に近縁の真菌であるた め, 組織内では特殊染色を行わない限り, Candida spp. と鑑別出来にく<, 生前 Trichosporon beigelii を検出し, Candida spp. による病変と記 載されたものは, 検出真菌と関連ありと判断した。 な敃肺ペニシリウム症例は，剖検時に培養検査を 行うと同時に病理所見を検討して診断されたもの である5 .

\section{成 績}

5 年間に, 血液から真菌が検出された症例 84 例
を年度別, 菌種別にまとめたものが, Table 1 であ る. 検出真菌のらち Candida albicans が単独に検 出されたものが最も多く, 全体の $39.3 \%$ 占め, 次いでC. parapsilosis $20.2 \%$, C. tropicalis $11.9 \%$ ，C. glabrata 10.7\%の順であった。死亡率 は年度別には，1986年は61.1\%，1987年は70\%， 1988年50\%，1989年 $46.7 \% ， 1990$ 年 $28.6 \%$ と 1989 年以降は減少傾向を示していた。これらの症例の 年齢別発生数は, Table 2 の通りで, 1 歳以上 30 歳 未満に少なく，1歳未満ならびに50歳以上に多く 認められた。男性は女性の 2 倍強であったが，死 亡率に男女差はなかった。 また基礎疾患別に見る と（Table 3), 消化器癌を含む固型癌が全体の $44.0 \%(37 / 84)$ を占め，次いで動脈瘤破裂などを 含めた心臓血管疾患が 9 例に見られた。その他癌 を除く消化器疾患 8 例，中枢神経系疾患之未熟児 および先天性疾患がそれぞれ 7 例などであった。

84例中76例に IVH カテーテルが插入されてい た汪か, 8 例に持続点滴が行われていたが, カテー 
Table 2 Age and sex distributions of cases complicated with fungemia

\begin{tabular}{ccccr}
\hline Year & Male & Female & \multicolumn{2}{c}{ Total } \\
\hline $1>$ & $4(3)$ & $4(1)$ & $8(4)$ & $(50.0 \%)$ \\
$1-9$ & 1 & & 1 & $(0.0 \%)$ \\
$10-19$ & $1(1)$ & & $1(1)$ & $(100.0 \%)$ \\
$20-29$ & 3 & & 3 & $(0.0 \%)$ \\
$30-39$ & $4(1)$ & $3(1)$ & $7(2)$ & $(28.6 \%)$ \\
$40-49$ & $4(2)$ & $2(1)$ & $6(3)$ & $(50.0 \%)$ \\
$50-59$ & $10(5)$ & $6(5)$ & $16(10)$ & $(62.5 \%)$ \\
$60-69$ & $12(7)$ & $4(2)$ & $16(9)$ & $(56.3 \%)$ \\
$70-79$ & $16(10)$ & $4(2)$ & $20(12)$ & $(60.0 \%)$ \\
$80 \leqq$ & $4(4)$ & $2(1)$ & $6(5)$ & $(83.3 \%)$ \\
\hline Total & $59(33)$ & $25(13)$ & $84(46)$ & $(54.8 \%)$ \\
\hline
\end{tabular}

( ) : number of deaths. (\%) : mortality rate.

Table 3 Underlying diseases and sex distributions of cases with fungemia

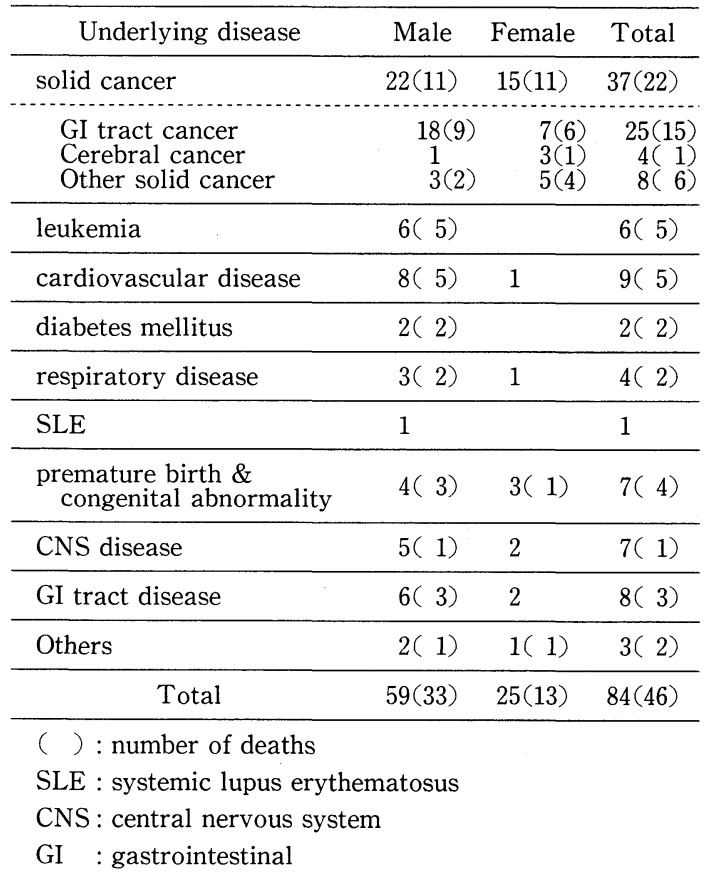

テルや持続点滴以外から真菌が侵入したと考えら れるものが 8 例認められた。 その内訳は，腹部大 動脈瘤破裂叔よびその術後に人工血管からの感染 と考えられるもの 2 例, 上腸管膜動脈瘤破裂 1 例, 心奇形 2 例および弁膜症術後 2 例, 前立腺肥大術 後 1 例であった。
Table 4 Autopsy findings in cases with fungemia (n:24)

\begin{tabular}{|c|c|}
\hline Fungal lesion & 8 \\
\hline systemic fungal lesions & 1 \\
\hline pulmonary fungal lesion & 1 \\
\hline systemic candidiasis & 2 \\
\hline systemic candidiasis \& CMV infection & 1 \\
\hline renal candidiasis & 1 \\
\hline pulmonary cryptococcosis & 1 \\
\hline pulmonary penicilliosis & 1 \\
\hline No fungal lesion & 7 \\
\hline Other findings & 7 \\
\hline sepsis & 1 \\
\hline pulmonary tuberculosis & 1 \\
\hline pyothorax & 1 \\
\hline pneumonia & 4 \\
\hline (including aspiration pneumonia) & \\
\hline Unknown & 2 \\
\hline
\end{tabular}

なお白血病患者や肝硬変患者では, nystatin, amphotericin B (AMPH) シロップあるいは flucytosine (5-FC) が予防的に投与されていたに もかかわらず，真菌血症を発症していた。

46例が死亡し，らち24例が剖検され，真菌病変 は 8 例に認められた。しかしこの 8 例のうち, 検 出真菌と異なる真菌による病変を認めた症例が 2 例あり，1例は肺クリプトコックス症, 他の 1 例 は肺ペニシリウム症であった。従って検出真菌と 病巣内の真菌が関連ありと考兄られた症例は 6 例 のみであった（Table 4)。そのほか何らかの感染 病巣を認めたものは, 細菌によるもので, 敗血症 1 例, 肺結核 1 例, 膿胸 1 例および肺炎 4 例であっ た.

IVH 施行中，動脈血・静脈血のいずれかか両方 から真菌が検出された症例，動脈血・静脈血のい ずれかあるいは両方からと IVH から同時に真菌 が検出された症例，1日あるいは数日の間隔で真 菌が連続して検出された症例, IVH のみから検出 された症例, IVH の挿入はなく持続点滴時に検査 を行って，真菌が検出された症例に分けて，真菌 病変との関係をみると, Table 5 のよらになる.即 ち動脈血, 静脈血のいずれかあるいは両方から真 菌が同時に検出された症例38例のうち22例が死亡 し，剖検例15例中 7 例に真菌病変が見られたが， 
Table 5 Source of positive culture and outcome

\begin{tabular}{|c|c|c|c|c|}
\hline $\begin{array}{l}\text { Source of } \\
\text { positive culture }\end{array}$ & $\begin{array}{l}\text { No. of } \\
\text { cases }\end{array}$ & $\begin{array}{l}\text { No. of } \\
\text { deaths }\end{array}$ & $\begin{array}{l}\text { No. of autop- } \\
\text { sied cases }\end{array}$ & $\begin{array}{l}\text { No. of cases showing } \\
\text { fungal lesion }\end{array}$ \\
\hline $\begin{array}{l}\text { Arterial and/or venous } \\
\text { blood }\end{array}$ & 38 & $\begin{array}{c}22 \\
(57.9 \%)\end{array}$ & 15 & $\begin{array}{l}\text { 7(including one case of pulmo- } \\
\text { nary penicilliosis and one } \\
\text { case of pulmonary cryptoco- } \\
\text { cosis) }\end{array}$ \\
\hline $\begin{array}{l}\text { Arterial and/or venous } \\
\text { blood and blood from IVH } \\
\text { catheter } \\
\text { (same time) }\end{array}$ & 11 & $\begin{array}{c}5 \\
(45.5 \%)\end{array}$ & 2 & 1 \\
\hline $\begin{array}{l}\text { Arterial and/or venous } \\
\text { blood and blood from IVH } \\
\text { catheter } \\
\text { (some days after) }\end{array}$ & 5 & $\begin{array}{c}5 \\
(100.0 \%)\end{array}$ & 1 & \\
\hline Blood from IVH catheter & 22 & $\begin{array}{c}9 \\
(40.9 \%)\end{array}$ & 4 & \\
\hline (Continuous drip infusion) & 8 & $\begin{array}{l}5 \\
(62.5 \%)\end{array}$ & 2 & \\
\hline Total & 84 & 46 & 24 & 8 \\
\hline
\end{tabular}

( ) : mortality rate

1 例は肺クリプトコックス症, 他の 1 例は肺ペニ シリウム症であった。動脈血，静脈血のいずれか あるいは両方からと IVH から同時に真菌が検出 されたものでは 1 例の真菌病変が認められた。 1
日あるいはそれ以上の間隔を打いて検出された 5 例は全て死亡していたが，症例数が少なく，真菌 血症との関連を追求出来なかった. IVH カテーテ ルから採取した血液のみから真菌を検出した症例

Table 6 Isolated fungi and autopsy findings

\begin{tabular}{|c|c|c|c|c|c|}
\hline Isolated fungi & $\begin{array}{l}\text { No. of cases } \\
\text { with fungemia }\end{array}$ & $\begin{array}{l}\text { No. of } \\
\text { deaths }\end{array}$ & $\begin{array}{l}\text { Mortality } \\
\text { rate }\end{array}$ & $\begin{array}{l}\text { No. of autop- } \\
\text { sied cases }\end{array}$ & $\begin{array}{l}\text { No. of cases with } \\
\text { fungal lesion }\end{array}$ \\
\hline Candida albicans & 33 & 18 & $54.5 \%$ & 11 & $\begin{array}{l}2 \text { (systemic and pulmonary } \\
\text { candidiasis) }\end{array}$ \\
\hline Candida parapsilosis & 17 & 7 & $41.2 \%$ & 1 & \\
\hline Candida tropicalis & 10 & 6 & $60.0 \%$ & 3 & $\begin{array}{c}2 \text { (systemic and renal can- } \\
\text { didiasis) }\end{array}$ \\
\hline Candida glabrata & 9 & 7 & $77.8 \%$ & 3 & $\begin{array}{l}2 \text { (pulmonary penicilliosis and } \\
\text { cryptococcosis) }\end{array}$ \\
\hline Candida guilliermondii & 4 & 2 & $50.0 \%$ & 2 & \\
\hline Candida krusei & 1 & & $0.0 \%$ & & \\
\hline Candida spp. & 1 & 1 & $100.0 \%$ & 1 & \\
\hline Trichosporon beigelii & 4 & 4 & $100.0 \%$ & 2 & $2(2:$ systemic candidiasis $)$ \\
\hline Sporothrix & 1 & & $0.0 \%$ & & \\
\hline $\begin{array}{l}\text { Candida albicans and } \\
\text { Candida tropicalis }\end{array}$ & 1 & 1 & $100.0 \%$ & 1 & \\
\hline $\begin{array}{l}\text { Candida albicans and } \\
\text { Candida glabrata }\end{array}$ & 1 & & $0.0 \%$ & & \\
\hline $\begin{array}{l}\text { Candida tropicalis and } \\
\text { Candida glabrata }\end{array}$ & 1 & & $0.0 \%$ & & \\
\hline $\begin{array}{l}\text { Candida parapsilosis and } \\
\text { Candida glabrata }\end{array}$ & 1 & & $0.0 \%$ & & \\
\hline Total & 84 & 46 & & 24 & 8 \\
\hline
\end{tabular}


では, 真菌病変は認められなかった。しかし血液 の採取方法別による死亡率に有意差は認められな かった。

次いで，検出真菌と剖検所見との関連を見ると (Table 6), C. albicans, C. tropicalis, T. beigelli を検出した症例では，それぞれ 2 例ずつに真菌病 変が認められたが，C. glabrataを検出した 9 例で は， 7 例が死亡し剖検は 2 例に行われているが， いずれも病変は検出真菌とは異なるCryptococcus neoformans および Penicillium spp. による ものであった，T. beigelii を検出した 4 例は全て 死亡し, 剖検例 2 例では共に真菌病変が認められ た。しかし検出真菌による死亡率に有意差はな かった.

血中から真菌が検出された後の処置・治療と予 後について検討したものが, Table 7 である.真菌 検出後, 何ら処置を行わなかった症例では, 32例 中24例が死亡し, 剖検例 16 例中 7 例に真菌病変が 認められている。しかし 7 例中，肺クリプトコッ クス症 1 例を除く 6 例では検出真菌による病変を 認めた. IVH カテーテルの抜去のみを行った症例 では，36例中15例が死亡し，5例に剖検が行われ ているが，明らかな真菌病変を有する症例はな かった。そのほかカテーテルを抜去した後, 抗真 菌剂を投与した症例11例のらち 6 例が死亡し, 剖 検が 2 例に行われ， 1 例に肺ペニシリウム症が認
められた。 カテーテル抜去例ならびに何ら処置を 行わなかった症例における死亡率は，それぞれ 41.7\%，72.7\%で，両者間に明らかな差が認めら れた $(\mathrm{p}=0.009)$.

尚今回検討した症例のらち, 真菌による眼内炎 は 6 例に認められた。

\section{考 察}

今回の集計に抢ける検出真菌の中で, 最も多い ものは C. albicans で40\%を占め, 次いで C. parapsilosis が20\%, C. tropicalis が12\%, C. glabrata が11\%の順で, このほか T. beigelii や Sporothrix spp. 認められた。 これまでの報告に和いても血 液から最も多く検出されるのは, C. albicansであ るが, その他の真菌の検出率は, 集計した症例の 基礎疾患や年齢構成の違いによって異なり ${ }^{6) ~ 9), ~}$ C. tropicalis は白血病に多く, C. parapsilosis 恃固 型癌や悪性腫瘍以外の基礎疾患を有する患者に多 いとする報告6)がある. 今回の集計では, 種々の疾 患が含まれていたこともあって, 以上のような結 果になったものかも知れない。な複数真菌血症 を11.6\%に認めた報告7)があるが，我々の集計で は 2 種の真菌を検出した症例は 4 例 $(4.8 \%)$ で あった。

84例中死亡率は $54.8 \%$ であり，これまでの報告

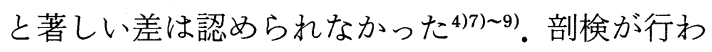
れた24例のらち, 真菌病変が認められた症例は 8

Table 7 Results of various countermeasures

\begin{tabular}{|c|c|c|c|c|c|}
\hline Countermeasure & $\begin{array}{l}\text { No. of } \\
\text { cases }\end{array}$ & $\begin{array}{l}\text { No. of } \\
\text { deaths }\end{array}$ & $\begin{array}{l}\text { (Mortality } \\
\text { rate) }\end{array}$ & $\begin{array}{l}\text { No. of autop- } \\
\text { sied cases }\end{array}$ & $\begin{array}{l}\text { No. of cases showing } \\
\text { fungal lesions }\end{array}$ \\
\hline none & 33 & 24 & $(72.7 \%)$ & 16 & $\begin{array}{l}\text { 7(including one case of pul- } \\
\text { monary cryptococcosis) }\end{array}$ \\
\hline Removal of catheter & 36 & 15 & $(41.7 \%)$ & 5 & \\
\hline $\begin{array}{l}\text { Removal of catheter and } \\
\text { surgical excision of skin } \\
\text { lesion }\end{array}$ & 1 & & $(0.0 \%)$ & & \\
\hline $\begin{array}{l}\text { Removal of catheter and } \\
\text { antifungal therapy }\end{array}$ & 11 & 6 & $(54.5 \%)$ & 2 & 1 (pulmonary penicilliosis) \\
\hline AMPH(i.v.) therapy & 1 & 1 & $(100.0 \%)$ & 1 & \\
\hline $\begin{array}{l}\text { Operation for abdominal } \\
\text { aneurysm and antifungal } \\
\text { therapy }\end{array}$ & 2 & & $(0.0 \%)$ & & \\
\hline Total & 84 & 46 & $(54.8 \%)$ & 24 & 8 \\
\hline
\end{tabular}

AMPH : amphotericin B. i.v. : intravenous drip infusion 
例で，このうち検出真菌と関係ありと考学られる ものは 6 例 $(25 \%)$ で，これまでの報告に見られ た $7.14 \%{ }^{9)} \sim 11.1 \%{ }^{10)}$ より高かった. 真菌血症を併 発したとしても，直接死因は基礎疾患によるもの も当然存在するわけで, 検出真菌が果たしてどの 程度死因に関与していたかは判断し難い。

検出真菌別に見ると，C. glabrata を検出した症 例では 9 例中 7 例が死亡し, 剖検で確認された真 菌病変は, いずれも検出真菌との関連が無かった のに対して，T. beigelii を検出した症例は全て死 亡し, 剖検された 2 例のいずれにも検出真菌に関 連する病変を認めていることから, 今後血液から T. beigelii が検出された場合は, 特に注意すべき であろら。

検討例は全て基礎疾患を有する院内感染例であ り，医原性疾患と言えよう。従ってその発生を阻 止することは特に重要である。これまで真菌血症 を惹起する risk factor として，1）長期間の顆粒 球減少，2）細菌血症の既往，3）持続する発熱,

4）広域あるいは複数の抗生剂の長期投与，5）経 静脈高カロリー栄養, 6) 血管内执よび尿管カテー テルの留置, 7）副腎ステロイド剤を含む免疫抑制 剂療法，8）手術(特に消化管手術)，9）弁置換術,

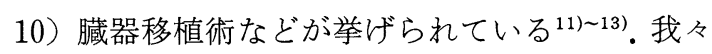
の症例は全例が 9,10)を除くいずれかの条件を 2 以上備えていた。

今回の検討では, 何の処置も行わなかった症例 33 例中 $72.7 \%$ が死亡し, 剖検でも真菌病変が最も 多く認められていたが, 生存例 9 例 (10.7\%) は 単なる contaminationであったものと推定され る。その活かカテーテル以外から真菌が侵入した と考えられる 8 例, また消化器癌などの術後に合 併した症例では, カテーテル以外からの侵入の可 能性もあり，いわゆるカテーテル関連真菌血症と して扱えるのは67例である。 カテーテル関連菌血

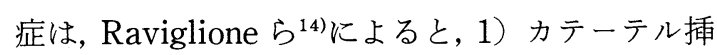
入部の感染, 2) 皮下組織内のトンネル感染, 3）力 テーテル抜去後 72 時間以内に解熱するカテーテル 菌血症，4）カテーテル敗血性静脈炎，5）カテー テル抜去後も発熱を認め, カテーテルの関与が強 く疑われる菌血症, 6) カテーテル以外の原因によ
る菌血症に分類されているが, 今回の検討例では, 皮膚插入部から皮下組織内のトンネル感染さらに 血栓性静脈炎を伴った症例が 1 例あった。 またカ テーテルの抜去のみで改善した21例（25\%）は3） に属し，45例は5）に属するものと考光られた。た だこれらの症例の中には, 肝硬変症と大動脈弁狭 窄があり, 下血のため入院中に IVH カテーテル を插入し, 治療中繰り返すカンジダ血症を起こし て死亡した症例では，下血の原因たる消化管病変 あるいはIVH カテーテルからの真菌の侵入があ り, 弁膜に vegetation を作り, 真菌血症を繰り返 したものと考觉られるが，これも5)に含めた。

真菌検出後, 何ら処置を行わない場合, 死亡率 が $72.7 \%$ と高く, 剖検例16例中 6 例 $(37.5 \%)$ r, 検出真菌と関連のある病巣が認められた。一過性 に真菌を検出したと考えられる症例では, IVH カ テーテル抜去後, 翌日から解熱傾向を示し， 2 日 目には平熱になることが多かった。

IVH 施行中に IVH カテーテルから採血した場 合を除いて，動・静脈血から真菌を検出した場合 には，病原的意義がより大きいものと考兄るべき であろう。また菌血症を疑って培養を行う時には, 同時にカテーテル先端（tip）や表在静脈をしごい て得られた血液の塗抹標本を作り, 分芽細胞では なく, 仮性菌糸が認められれば, 培養の結果をま つことなく, 診断がつき治療を早期に行らことが 出来るため, 塗抹検査を推奖する報告がある ${ }^{15) 16)}$. 本邦では中央検査室が充実してきたため, 臨床の 場に招いて，単に培養を行えば良いとする風潮が あることは憂らべきことである。

また血液培養で真菌が検出された場合には，眼 科的検索を繰り返し行うべきとされる.今回は 6 例に眼内炎を認めたが, 真菌血症に眼内炎を認め る割合は，本邦に扔いては数\%とされている。乙 かし繰り返し検索することによって，28\%～37\% に眼内炎が見られると言ら報告もある ${ }^{17) 18)}$. 眼内 炎は治療を開始しても，直ちに軽快するものでは ないため, 経過を追って繰り返し検索する必要が あろう。

ただ白血病や悪性リンパ腫患者では, AMPH シロップや5-FCの予防投与は腸管内真菌の増殖 
はある程度抑制できるとしても，経気道的に侵入 する感染あるいはカテーテルなどを介する感染の

予防には無効と考兄られた。

稿を終わるにあたり, 御指導・御鞭撻戴きました恩師,

順天堂大学医学部教授池本秀雄先生に心から感謝致しま す.

\section{文献}

1) Hotchi, M., Okada, M. \& Nasu, T.: Present state of fungal infections in autopsy cases in Japan ; a statistical survey of all autopsy cases during the ten-years period from 1966 to 1975 . Am. J. Clin. Path., 74: 410-416, 1980.

2) 奥平雅彦: Opportunistic fungus infection $の$ 病 理. 日病会誌, $74: 61-91,1985$.

3) Bodey, G.P.: Candidiasis in cancer patients. Am. J. Med., 77(Suppl.) : 13-19, 1984.

4) Harvey, R.L. \& Myers, J.P.: Nosocomial fungemia in a large community teaching hospital. Arch. Intern. Med., 147 : 2117-2120, 1987.

5) Mori, T., Matsumura, M., Kohara, T., Watanabe, Y., Ishiyama, T., Wakabayashi, Y., Ikemoto, H., Watanabe, A., Tanno, M., Shirai, T. \& Ichinoe, M. : A fatal case of pulmonary penicilliosis. Jpn. J. Med. Mycol., 28 : 341-348, 1987.

6) Komshian, S.V., Uwaydah, A.K., Sobel, J.D. \& Crane, L.R.: Fungemia caused by Candida species and Torulopsis glabrata in the hospitalized patient; frequency, characteristics and evaluation of factors influencing outcome. Rev. Infect. Dis., 11: 379-390, 1989.

7) Lin, H., Liu, Y., Liu, C. \& Cheng, D.: Fungemia ; analysis of 43 cases. J. Formosan. Med. Assoc., 89 : 863-867, 1990.

8) Dyess, D.L., Garrison, R.N. \& Fry, D.E. : Candida sepsis; implications of polymicrobial blood-borne infection. Arch. Surg., 120:345 $-348,1985$.

9）磯崎泰介, 岡慎一, 深山牧子, 浦山京子, 稲松 孝思：真菌血症51症例の臨床的検討. 感染症誌,
$60: 829-833,1986$.

10）川畑信也，横内正利，大友英一：老年者に拁ける カンジダ血症22例の臨庄病理学的検討. 日老医会 誌, $27: 45-51,1990$.

11) Bross, J., Talbot, G.H., Maislin, G., Hurwitz, S. \& Strom, B.L.: Risk factors for nosocomial candidemia; a case-control study in adults without leukemia. Am. J. Med., 87 : 614-620, 1989.

12) Edwards, J.E. Jr.: Candidemia and Candida catheter-associated sepsis. In Diagnosis and Therapy of Systemic Fungal Infections (Holmberg, K. \& Meyer, R., ed.), p. 39-46, Raven Press, Ltd., New York, 1989.

13) Richet, H.M., Andremont, A., Tancrede, C., Pico, J.L. \& Jarvis, W.R.: Risk factors for candidemia in patients with acute lymphocytic leukemia. Rev. Infect. Dis., 13: 211-215, 1991.

14) Raviglione, M.C., Battan, R., Pablos-Mendez, A., Aceves-Casillas, P., Mullen, M.P. \& Taranta, A.: Infections associated with Hickman catheters in patients with acquired immunodefficiency syndrome. Am. J. Med., 86 : 780-786, 1989.

15) Portnoy, J., Wolf, P.L., Webb, M. \& Remington, J.S.: Candida blastospores and pseudohyphae in blood smears. N. Engl. J. Med., $285: 1010$ $-1011,1971$.

16) Buchman, A.L., Lee, S., Miller, J. \& Voldecantos, A.: Candida fungemia diagnosed from peripheral blood smear. J.A.M.A., 260 : 2926, 1988.

17) Brooks, R.G.: Prospective study of Candida endophthalmitis in hospitalized patients with candidemia. Arch. Intern. Med., 149: 2226 $-2228,1989$.

18) Parke, D.W., Jones, D.B. \& Gentry, L.O. : Endogenous endophthalmitis among patients with candidemia. Ophthalmology, $89: 789-796$, 1982. 
Analysis of 84 Cases with Fungemia

Shinhachi NAKAZAWA, Takeshi MORI, Ichirou HIBIYA \& Toyoko OGURI*

Division of Infectious Disease, Department of Internal Medicine, Juntendo University School of Medicine $\&$ *Clinical Laboratory, Juntendo University Hospital

Eighty-four patients with fungemia were analyzed. Fungi had been isolated by culture of blood samples, including blood from the catheter for intravenous hyperalimentation, between 1986-1990.

Candida albicans (39.3\%), Candida parapsilosis (20.2\%), Candida tropicalis (11.9\%), Candida glabrata (10.7\%), Candida guilliermondii (4.8\%) and Trichosporon beigelii (4.8\%) were the most frequently isolated fungal pathogens. Four patients' blood yielded two different fungal species. Fifty-nine cases were male, and 25 cases were female. Forty-six of the 84 patients died (54.8\%), but there were no differences in the overall mortality rate as a function of the fungal species or sex.

All patients had underlying diseases: solid cancer, 37 cases; cardiovascular diseases, 9 cases; gastrointestinal diseases excluding gastrointestinal cancer, 8 cases; central nervous system diseases, 7 cases; premature infants and congenital abnormality, 7 cases; leukemia, 6 cases and miscellaneous, 10 cases.

Twenty-four of the 46 dead cases were autopsied, and eight cases showed systemic fungal lesions. However, in one case of pulmonary cryptococcosis and one case of pulmonary penicilliosis, there was no correlation between the isolation of $C$. glabrata by blood culture and the pathological findings.

A fungus-positive blood culture was surmised to be a result of contamination of the sample in 33 cases, and the mortality rate for those cases was $72.2 \%$ (24 cases). For 6 of the corpses, fungal lesions observed at autopsy were compatible with the types of lesions found by the fungi which had been isolated before death. Removal of the catheter reduced the mortality rate to $41.7 \%$. Fungal endophthalmitis was diagnosed in six cases.

If fungi are isolated from a blood culture, any indwelling catheters, should be removed, and blood cultures and careful examination for fungal endophthalmitis should be repeated. 